Információközvetítés és közösségépítés - multifunkciós könyvtári hálózatok. Szerk. Kiszl Péter, Németh Katalin. Budapest, ELTE BTK

Könyvtár- és Információtudományi Intézet. 2020. 41-54.

\title{
INFORMÁCIÓKÖZVETÍTÉS ÉS KÖZÖSSÉGÉPÍTÉS A REÁLTUDOMÁNYOK MÜVELÖI KÖRÉBEN MAGYARORSZÁGON 1825-1867
}

\author{
GAZDA IsTVÁN
}

\section{TARTALMI ÖSSZEFOGLALÓ}

Bécs 1825-től kezdve engedélyezte, hogy Magyarországon országos hatókörü vagy helyi tudományos társaságok és egyletek jöjjenek létre. Legismertebb az összes tudományágra kiterjedő egyesülés, a Magyar Tudós Társaság, de a reáltudományok szakemberei ezen túlmenően önálló társaságokat is alapítottak. Ezek lettek az információközvetítés és közösségépítés legfőbb színterei, melyben élen jártak az orvosok és a gyógyszerészek. Az éves vándorgyüléseiket is igyekeztek úgy szervezni, hogy a történelmi Magyarország mindazon városaiba eljussanak, amelyek vagy nagy kórházzal, vagy jelentős gyógyforrással rendelkeztek, így a felvidéki s az erdélyi településekre is.

Az 1825-1867 közötti időszakot vizsgálva, az információközvetítés szempontjából jelentős szerep jutott a tudományos periodikáknak. Megindult az Orvosi Tár, majd az Akadémia és a Természettudományi Társulat periodikái, a Vándorgyülések Évkönyvei, a Magyarhoni Földtani Társulat lapja, az Orvosi Hetilap és a Gyógyászat, a Vegyészet és Gyógyszerészet, illetve a már említett megyei egyletek periodikái. Ne feledkezzünk el Magyarország második akadémiájának, az Erdélyi Múzeum-Egyletnek a központi lapjáról, valamint reáltudományi folyóiratáról, s arról se, hogy 1867-ben indította az Akadémia - a hosszú évtizedeken át megjelenő - reáltudományi periodikáit.

A tudományos ismeretek átadásának további színterét a szakkönyvek jelentették. A reáltudományi helytörténetírás első nagy rejtett könyvsorozata a Magyar Orvosok és Természetvizsgálók Vándorgyüléseihez kötődtek, majd létrehozták a Magyar Orvosi Könyvkiadó Társulatot is, utóbbiak részben fordításokat, részben hazai szerzők müveit adták közre. És az Akadémia is igyekezett - mecénások bevonásával - néhány jelentős reáltudományi művet közreadni.

\section{A Magyar Tudós Társaság közösségépitő szerepe a reáltudományok területén}

A reformkor időszakában az elsősorban a humán müveltséget gyarapító olvasókörökön túlmenően a közösségépítésben úttörő szerep jutott az 1825-ben megalapított, s 1830-tól működő Magyar Tudós Társaságnak, vagyis az Akadémiának. Fő céljuk a nyelv- és széptudományok művelése volt, de ügyeltek a reáliákra is. A Társaság kiadói tevékenysége 1832-ben indult, ${ }^{1} \mathrm{~s}$ a vizsgált időszakban több természettudományi, orvosi és matematikai könyvet, valamint egy müszótárt is közreadtak, s periodikáiban is sok hasznos szakcikk jelent meg a reáliák különböző ágaiból. ${ }^{2}$ 


\section{Gazda István}

Közösségépités és a szakszavak gyártása

Az 1831-es kolerajárvány mindenkit óvatosságra intett, s jó ideig a Társaság sem vállalta, hogy havi vagy heti üléseket tartson, így közösségépítésre kizárólag a postai úton történő érintkezés adott lehetőséget. Nagy közösségformáló feladatuk volt, hogy minden tudományterületre kiterjedően kezdjék el a szaknyelv megújítását, szótározását, s ez valóban megpezsdítette a hazai tudósvilágot, ötletes és borzalmas szószülemények egyaránt készültek, postára adattak és vitára bocsáttattak.

Szógyüjtésük első eredménye volt a matematika szaknyelvét szótározó kötetük, a Mathematikai müszótár, amely az egységesülő szaknyelv kialakítása szempontjából értékes összeállítás. ${ }^{3} \mathrm{Ez}$ a szószedet az információközvetítés szempontjából is fontos kiadvány, hiszen a mű sok-sok kutató és tudományos műhely nyelvjobbító, nyelvújító javaslatait gyüjtötte össze és adta közre. Ennek elkészítésében az akadémikusok mellett több gimnázium tanári közössége is részt vett. A téma egyik jeles gyüjtője, javaslattevője az akadémikus Bolyai Farkas, a marosvásárhelyi református kollégium tanára volt. ${ }^{4}$

A további szójobbítási ötletek, próbálkozások másik csoportja az 1858-as német-magyar iskolai müszótárban kapott helyet, ${ }^{5}$ ennek a munkálataiba - sok más mellett - az akkor akadémikussá lett Jedlik Ányos is bekapcsolódott, s az orvos Bugát Pál akadémikus lett a szógyártás leglelkesebb híve. ${ }^{6} \mathrm{Az}$ egész folyamatot korrekten összegezte 1861-ben Szabó József, a földtan akadémikusa, a Magyarítás a természettudományokban s különösen annak gyakorlati jelentősége címü alapvető dolgozatában. Negyven évvel később, a századfordulón a fizikus-nyelvtörténész akadémiai fótitkár, id. Szily Kálmán a nyelvújítás főbb eredményeit szótározta is. ${ }^{7}$

Egy fejezet a nemzetközi kapcsolatok történetéből

A Tudós Társaság a 30-as évek elején kezdte kiépíteni nemzetközi kapcsolatait, ekkor lépett érintkezésbe más társaságokkal (Amerika, Nagy-Britannia, Németország, Franciaország), és alakult ki közöttük egy nemzetközi csere: hazai akadémiai kiadványokért kaptak cserébe külföldi tudóstársasági folyóiratokat, s szerencsére ez a ritkaság-gyüjtemény fennmaradt.

De nemcsak cserekapcsolat alakult ki, hanem az akadémikus Nagy Károly ${ }^{8} 1834$ ben a Szigetország egyik tudósa jóvoltából egy különleges művet bocsátott közre, London és Pest-Buda közös kiadásában. Nagy Károly ugyanis jó kapcsolatba került Charles Babbage neves angol matematikussal és műszaki alkotóval, az MTA későbbi tiszteletbeli tagjával, s együtt rendezték sajtó alá azt a logaritmustáblát, amelyet Londonban nyomtak a pesti Akadémia költségén. Ez a magyar könyvkiadás egyik különlegessége, hiszen ez az eredeti angol mü magyar szakember által javított londoni kiadása, amely háromfajta színes papíron jelent meg, különböző nyelvű előszavakkal. ${ }^{9}$

A már említett matematikai szótárban lévő kifejezések csak javaslatok voltak, a szakma még nem döntött, hogy közülük melyeket fogadja el, ezért is írták a logaritmustábla hivatalos mellékletében, hogy a müben szereplő szakkifejezésekért a Társa- 
ság nem vállal felelősséget. Ezt akkoriban minden akadémiai kiadványba beleírták, Babbage műve esetében mindez talán fölösleges volt, hiszen a több száz oldalas mű - néhány bevezető gondolatot követően - lényegében két szót tartalmaz csupán: log és num, a többi pedig szám.

Zárt közösség a matematikusok világában

A Magyar Tudós Társaság matematikusai igencsak zárt közösséget alkottak: keveseket fogadtak be maguk közé, ${ }^{10}$ az elfogadott, könnyen megérthetö matematikán túlmutató ötletekkel, beadványokkal pedig nem kívántak foglalkozni. ${ }^{11}$ Ennek kirívó példája, hogy - vizsgált időszakunkban - Bolyai János geometriája nem tudott befurakodni a pest-budai matematikus körökbe, nem talált értőre, követöre. Műve 1833-tól ott feküdt a Társaság könyvtára polcán, de háborítatlanul, felvágatlanul vagy 35 éven át, míg egy külföldi tudós fel nem hívta rá Eötvös József miniszter úr figyelmét. ${ }^{12}$ Különösen sértő, hogy Bolyai János nem-euklideszi, tehát a valódi teret (mondhatni a görbült teret) leíró geometriája akadémiai elismerése helyett az évszázadokkal korábbi euklideszi síkgeometria komolyabb elismerést és megértést kapott. 1865-ben ugyanis Euklides 15 fejezetből álló Elemeinek egyetlen teljes magyar fordítása jelent meg a Társaság költségén, Brassai Sámuel fordításában. ${ }^{13}$ Ebben található az a párhuzamossági axióma, melynek igaz vagy nem igaz voltától független tárgyalásban dolgozta ki Bolyai János, az egykoron nagyon kevesek által megértett, de azóta világhírűvé lett, $\mathrm{s}$ az UNESCO által is a szellemi világörökség részéve nyilvánított geometriáját. ${ }^{14}$

\section{Az élö természet tudományai}

Az Akadémia korai biológiai kiadványai között jelentős volt Cuvier híres állattanának magyar fordítása (Vajda Péter jóvoltából), de abból sajnos csak az első kötet jelent meg, a második - pénz hiányában - kéziratban maradt. ${ }^{15} 1860$ után tünik fel a zoológus és anatómus Margó Tivadar, a magyarországi tudományos biológia egyik megalapozója, valamint a madártan legnagyobbja, Petényi János Salamon. ${ }^{16}$ (Herman Ottó Petényit tekintette legfőbb tanítómesterének.) Sok publikáció kötődik Frivaldszky Imre és unokaöccse, Frivaldszky János nevéhez, mindketten zoológusok volta, egyben a Magyar Nemzeti Múzeum jeles vezetőiként tisztelték őket. Hunfalvy János három kötetben adja közre A magyar birodalom természeti viszonyainak leírását.

Ekkor kezd el publikálni a vegytan területén, a korábban Bécsben tanult Than Károly, aki a Tudományegyetem professzoraként müködött. ${ }^{17}$ Neves elődje volt Nendtvich Károly müegyetemi professzor, akit egykoron sokan azért ismertek, mert Kossuth Lajos felkérésére a Magyar Országos Iparegyesületben vasárnap és ünnepnapokon az iparosok számára népszerủ előadásokat tartott vegytanból. Maga az Iparegyesület ezekkel a programjaival lett a közösségépítés fontos reformkori színtere.

Az orvostudomány csak lazán kötődött az Akadémiához, amely ennek megfelelően nagyon kevés orvosi munkát adott közre. Az orvosok már 1831-től kezdődően önálló 


\section{Gazda István}

periodikával rendelkeztek ugyan, de az Akadémián kívül. Ez volt az Orvosi Tár, amelynek szerkesztésében 1831-32-ben az orvosi diplomával rendelkező Toldy (Schedel) Ferenc is részt vett, aki 1834-35-ben az Akadémia lapjának, a Tudománytárnak volt az egyik szerkesztője, majd 1835 őszétől a Tudós Társaság második főtitkáraként müködött.

Jelen sorok szerzőjének az a véleménye - s ezt elsőként itt adja közre -, hogy az orvos Toldy az orvosok müveit nem óhajtotta az Akadémia érdekkörébe vonni. Ennek az lehetett az oka, hogy az ezzel kapcsolatos támadásokat szerette volna elkerülni. Elődje, az első főtitkár (titoknok) ugyanis az a Döbrentei Gábor volt, aki a reformkor legelegánsabb és legdrágább akadémiai kiadványaiként saját szövegátiratait adta közre, Régi magyar nyelvemlékek címen. Ezzel kapcsolatban még Széchenyi is nemtetszésének adott hangot. (Arról nem is beszélve, hogy ezek a kiadványok nem voltak a szakma remekei, amit abból is látunk, hogy évekkel később Volf György kénytelen volt Döbrentei valamennyi kötetét úgymond újraírni, s a Nyelvemléktár sorozatban újra közreadni.)

Toldy az Akadémia szerény könyvkiadási keretéből egyetlen saját orvosi művet sem adott közre, s egyetlen irodalomtudományi anyaga sem jelent meg az Akadémia költségén. Az orvosok közösségét külön építette fel, függetlenítve őket a Magyar Tudós Társaságtól.

Igazodott viszont az Akadémia egyik központi elvárásához, a nyelvműveléshez, s ennek körében adta közre a Magyar-deák és deák-magyar orvosi szókönyv az Orvosi Tár első két évéhez (1833) címü összeállítását, valamint Vörösmartyval együtt a $M a$ gyar és német zsebszótárat.

Ami a megjelent akadémiai orvosi műveket illeti, közülük kiemelkedő értéket képvisel Fabini János Teofil akadémikusnak, a szemészet első hazai egyetemi profeszszorának szakkönyve, amely először latinul jelent meg, majd a Tudós Társaság kiadásában magyarul, 1837-ben. ${ }^{18}$ Kötetet adott ki az Akadémia a pokolvarról (lépfenéről) is, ez pályamunkákat tartalmazott, ${ }^{19} \mathrm{~s}$ közreadta Chelius sebészetét négy kötetben Bugát Pál fordításában. Utóbbi elsősorban szaknyelvi szempontból jelentős vállalkozás. ${ }^{20} 1867$-ben jelenik meg Balassa János első plasztikai sebészeti munkája akadémiai kiadásban, ekkor kerül ki a sajtó alól Lenhossék József idegtudományi munkája, Jendrassik Jenő szemészeti értekezése és Rózsay József járványtani dolgozata. Az azonban már fel sem merült, hogy Semmelweiset tagjai sorába fogadja a Magyar Tudományos Akadémia is, holott ő megküldte a testületnek az 1860-ban megjelent, később világhírűvé lett német nyelvű munkáját, de annak jelentőségét csak évekkel később ismerték fel. ${ }^{21} \mathrm{Az}$ Akadémia - mint információközvetítő testület - sokat segíthetett volna Semmelweisnek abban, hogy tanai mellé áll, s a külföldi akadémiákhoz is eljuttatott periodikáiban elismerőleg ír róla. Ez sajnos nem történt meg, hiszen az orvosok is ugyanolyan zárt egységet alkottak az Akadémián belül, mint a matematikusok, s a még teljességében nem bizonyított tudományos felismerésekkel óvatosan bántak. Az az érzésünk, hogy az akadémiai testületre ez még manapság is jellemző. Jóval nyitottabbak voltak viszont az Akadémiától független orvosi egyesületek, egyletek. 
INFORMÁCIÓKÖZVETÍTÉS ÉS KÖZÖSSÉGÉPÍTÉS A REÁLTUDOMÁNYOK MÜVELŐI...

Egy információközvetitő szereppel bíró akadémiai bibliográfia-sorozat

Nemigen szoktak szólni arról, hogy elsősorban Toldy kezdeményezésére az Akadémia lapjában, a Tudománytárban egy, a nemzeti bibliográfia fontos részét képező éves kurrens szakbibliográfiai sorozat is megjelent Magyar bibliographia címmel, mégpedig az 1831-től 1843-ig terjedő időszakról. A bibliográfia részben azokat a műveket tartalmazza, amelyek beérkeztek a tudós testület könyvtárába, részben pedig azokat, amelyeknek a címeit a tagok megküldték a szerkesztőségnek.

1831-ről. = Tudománytár. Második kötet (1834) pp. 197-213.

1832-ről. = Tudománytár. Harmadik kötet (1834) pp. 192-209.

1833-ról. = Tudománytár. Hatodik kötet (1835) pp. 228-249.

1834-ről. = Tudománytár. Hetedik kötet (1838) pp. 195-216.

1835-ről. = Tudománytár. Tizedik kötet (1838) pp. 207-214.

1836-ról. = Tudománytár. Literatura. Első kötet (1837) pp. 473.483.

1837-ről. = Tudománytár. Literatura. Második kötet (1838) pp. 392-412.

1838-ról. $=$ Tudománytár. Literatura. Harmadik kötet (1839) pp. 443-470.

1839-ről. = Tudománytár. Literatura. Negyedik kötet (1840) pp. 477-502.

1840-rőll. = Tudománytár. Literatura. Ötödik kötet (1841) pp. 489-526.

1841-ről. = Tudománytár. Literatura. Hatodik kötet (1842) pp. 481-512.

1842-ről. = Tudománytár. Literatura. Hetedik kötet (1843) pp. 481-505.

1843-ról. = Tudománytár. Literatura. Nyolcadik kötet (1844) pp. 477-505. ${ }^{22}$

A sorozat folytatása az Eggenberger József és Fia cég gondozásában megjelent kereskedelmi célú Honi irodalmi hirdető. Kevéssé ismert adat, hogy ezen a periodikán szerepel, hogy az 1843-as és 1844-es jegyzék a Tudománytár hivatalos melléklete. A Tudománytár 1844-ben megszűnt, a jegyzék viszont továbbra is megjelent, s mivel Eggenbergerék az Akadémia hivatalos könyv- és folyóirat-terjesztői voltak, ezért a sorozat további részét is tekintsük közös kiadásnak.

1843-ról. = Honi irodalmi hirdető. I. év (1843) 56, [10] p.

1844-ről. = Honi irodalmi hirdető. II. év (1844) 56, [10] p.

1845-ről. = Honi irodalmi hirdető. III. év (1845) 50, [4] p.

1846-ról. = Honi irodalmi hirdető. IV. év (1846) 48, [4] p.

1847-röl. = Honi irodalmi hirdető. V. év (1847) 52, [6] p.

1848-ról. = Honi irodalmi hirdető. VI. év (1848) 47 p. ${ }^{23}$

A Bach-korszakban (1850 és 1860 között) az Akadémia központi lapja az Új Magyar Múzeum volt, s ennek Irodalmi napló rovatában folytatódott a Tudománytárban elindult bibliográfiai vállalkozás. 


\section{Gazda István}

\section{Az orvostudományi és gyógyszerészi társaságok}

Az orvosok 1837-ben két - az Akadémiától független- tudóskört is alapítottak: az egyik a Budapesti Sebészegylet, a másik a Budapesti kir. Orvosegyesület. Utóbbinak Toldy is alapító tagja volt, s tagja lett a kor valamennyi jeles hazai orvosa, köztük Semmelweis is (utóbbi látogatta is az egylet üléseit).

Az orvosok 1944-ig müködő legnagyobb egyesülete az 1837-ben alapított Kir. Orvosegyesület volt, könyvtáruk 1945 után a Semmelweis Orvostörténeti Könyvtár alapjául szolgált. ${ }^{24}$ Ennek mintájára (és hírére) 1838-ban létrejött a Temesvári Orvosegyesület, 1839-ben pedig a Nyitrai Orvosegyesület. Utóbbi az egyik legnagyobb taglétszámmal működő vidéki orvostársaságnak számított, népszerüségét növelték az évente megrendezett nyári nagygyüléseik is, amelyet a tagokon kívül vidéki és fővárosi orvosok is nagy számban látogattak. Ugyancsak 1839-ben jött létre a Szatmári Orvosegyesület és a Miskolczi Orvosegyesület is (utóbbi 1841-ben feloszlott, de 1847-ben újjáalakult). Az újjászervezett Miskolczi Orvosegyesület eredményes müködését bizonyítja, hogy 1847-ben elkészítette a megye növényzeti térképét, javaslatot terjesztett fel az orvoskar reformjára, valamint véleményező szerepet töltött be a megyében közegészségügyi kérdésekben.

1840-ben Nagyszebenben alakult meg a Verein für siebenbürgische Landeskunde, a szászok és a magyarok közös honismereti-természetrajzi-nyelvészeti egylete.

1846-ban Pápán, 1848-ban Eperjesen jött létre orvosegyesület. Pozsonyban 1856-ban alakult meg a hosszú évtizedeken át fennálló Orvos-Természettudományi Egyesület. 1859-ben jött létre Kolozsvárott a ma is müködő Erdélyi Múzeum-Egylet, amely később önálló orvos-természettudományi szakosztállyal is bővült. (1876-ban alakult meg a kolozsvári Orvos-Természettudományi Társulat, amely később beolvadt az Erdélyi Múzeum-Egyletbe.) 1867-ben hozták létre a Szepesi Orvos-Gyógyszerész Egyletet és a Gömörmegyei Orvos-Gyógyszerész Egyesületet. 1869-ben alakult a Zemplénvármegyei Orvos-Gyógyszerész Egyesület, a következő évben pedig a Selmeczi Gyógyászati és Természettudományi Egylet.

Az orvosegyleteken túlmenően a Királyi Magyar Természettudományi Társulat mintájára jött létre 1874-ben a Délmagyarországi Természettudományi Társulat, 1877-ben pedig a Trencsénmegyei Természettudományi Egylet. Hamarosan több megyei „történelmi, régészeti és természettudományi egylet” is alakult.

Nyilvánvaló, hogy mindezek a közösségépítés alapvető fórumai voltak, s a kor nehézkes közlekedési viszonyai nemigen tették lehetővé, hogy az orvosok és gyógyszerészek sürün eljussanak a távolabbi városok rendezvényeire, éppen ezért, ahol csak tehették, önálló periodikában közölték az elhangzottakat rögzítő szakmai írásokat, s az egyletek munkájának leírását. Ezek a periodikák voltak az információközvetítés színterei a hazai mobilabb közlekedés kialakulásáig. Ami a gyógyszerészeket illeti: Láng Adolf Ferenc nyitrai gyógyszerész 1848-ban Nyitrán indította útjára az első magyar nyelvü, 
kifejezetten gyógyszerészi lapot, a Gyógyszerészi Hirlapot, amely - nyilván a politikai események következtében - kilenc szám megjelenése után megszűnt. Még 1867 előtt megindult két újabb szaklapjuk: a Gyógyszerészi Hetilap (Schédy Sándor gyógyszerész alapította 1862-ben), valamint a Vegyészet és Gyógyszerészet (1863-1865 között jelent meg Felletár Emil szerkesztésében). Volt egy testületük is, az 1809-ben alapított BudaPesti Gyógyszerészek Testülete, s ők adták ki az első gyakorlati és oktatási célokra is használható háromkötetes gyógyszerészeti kézikönyvet Felletár Emil - Kátai Gábor: A gyógyszerészeti tudományok alapvonalai (Pest, 1864-1867) címmel. Ezen túlmenően 1841-ben megalakították a Budapesti Gyógyszerészsegédek Betegápoló Egyesületét.

\section{Az orvosok és természettudósok éves vándorgyülései 1841 és 1867 között}

Helyi és országos egyleteket is alapítottak az orvosok és a természettudósok is. De az igazi információközvetítők mégiscsak az éves vándorgyülések voltak, amelyeket 1841-től kezdődően az ország más-más városában tartottak. Minden évben 3-4 napra gyűltek ott össze a tudósok, kezdetben 1841 és 1847 között, majd a tiltott éveket követően 1863-tól ismét. Mi most csak 1867-ig követjük a történéseket, amelyeket azért tudunk megtenni, mert e nagy rendezvények anyaga utólag mindig könyv formájában is megjelent, sőt ahol tehették, még külön szakmai kiadványokat is készítettek a rendezvények tiszteletére. Ezek többnyire helytörténeti jellegủ művek voltak.

Az első összejövetelt Bene Ferenc orvosdoktor kezdeményezésre tartották 1841-ben Pesten, a másodikat ugyanabban az évben ugyanott. Ezt követte 1842-ben a besztercebányai, 1843 -ban a temesvári, 1844-ben a kolozsvári, 1845-ben a pécsi, 1846-ban a Kassaeperjesi, s 1847-ben a soproni. Hosszú szünet után 1863-ban Pesten találkoztaka tudósok, 1864-ben Marosvásárhelyen, 1865-ben Pozsonyban, 1867-ben pedig Rimaszombatban.

Gondoljuk el, hogy több száz természettudós, orvos és müszaki alkotó látogatott el a vándorgyülésekre abban az időszakban, amikor a vasúti közlekedés még nem indult be az országban. Egy pesti tudós számára Temesvár, Marosvásárhely vagy Kassa bizony komoly utazási időt jelentett. Mégis rászánták az időt a nem mindig kellemes utazásra, hogy találkozhassanak tudóstársaikkal, meg hogy előadást tartsanak legújabb tudományos felismeréseikről. ${ }^{25}$

Ami a vándorgyűlések alkalmából megjelent kiadványokat illeti, nagyszámú kiadvány készült az ülések tiszteletére 1867-ig. Néhány példa: a 3. nagygyülésre Zipser $K$. András adott ki egy nagy monográfiát, ${ }^{26}$ a következőre Wachtel Dávid doktor lefordította Hippokrates aforizmáit. ${ }^{27}$ 1843-ban jelent meg Deutsch József Buziásról szóló balneológiai műve, ${ }^{28}$ 1842-re kötetet adott ki Zipser Keresztély Besztercebányáról, 1845-ben pedig Baranyáról írt Haas Mihály. ${ }^{29}$ Bittner Imre járványtani dolgozata 1847 -es. ${ }^{30} \mathrm{~A} 7$. nagygyülés tiszteletére Sáros megyéről publikáltak, s adtak ki könyvet a Czigelka gyógyforrásról. A nyolcadikra jelent meg Mocsi Mihály értekezése. ${ }^{31} \mathrm{~A}$ kilencedikre a Semmelweis tanait el nem ismerő Virchow sejtkórtanát méltatták kü- 


\section{Gazda István}

lön kötetben, ${ }^{32}$ és ekkor készült Balassa remek plasztikai sebészeti munkája. ${ }^{33}$ Véleményünk szerint a vándorgyülések tiszteletére megjelent honismereti munkák egyfajta rejtett helytörténeti sorozatot alkotnak (a gyüléseket 1841-től 1933-ig rendezték meg).

A Királyi Magyar Természettudományi Társulat (alapitva: 1841)

Szintén 1841-ben alakult, mégpedig 134 taggal. Alapítóként a szaknyelv megújítójaként is a már emlegetett Bugát Pált tisztelik. 1869-ig szaktudományi szervezetként müködtek, ezt követően elsősorban a tudományos ismeretterjesztésre helyezték a hangsúlyt. Évkönyveket adtak ki és egy szaklapot is a Magyar Természettudományi Társulat Közlönye címmel, 1860 és 1868 között. Híres, a mai napig fennálló periodikájuk, a Természettudományi Közlöny 1869-ben indult (jelenleg Természet Világa föcímmel jelenik meg). A Társulat a természettudósok nagy közösségének legfőbb összefogó szervezete volt, periodikáik pedig a modern tudományos információk fontos népszerüsítői és továbbítói voltak. ${ }^{34}$

\section{Orvosi Hetilap, a Gyógyászat és a Magyar Orvosi Könyvkiadó Társulat}

Már szó volt arról, hogy az Orvosi Tár című havilap 1831-től kezdődően jelent meg, első ciklusa 1833-ig tartott. Új folyama 1838 és 1848 között látott napvilágot. Az újabb magyar nyelvü orvosi periodika kiadása Markusovszky Lajos szervezőmunkájának köszönhetően indult meg 1857 második félévében. Ez a - címében már a hetente történő megjelenést hirdető - Orvosi Hetilap, amely szerencsére azóta is közreadatik. ${ }^{35}$ Ebben jelent meg elsőként - cikksorozat formájában - Semmelweis beszámolója a gyermekágyi láz okairól.

A Hetilap igyekezett az orvosi szakma minden területéről ide vonzani az olvasókat és szerzőket, amit részben a lap mellékleteivel ért el: Nő- és Gyermekgyógyászat (indult 1864-ben), Szemészet (indult 1864-ben), Közegészségügyi és Törvényszéki Orvostan (indult 1865-ben). A nőgyógyászati periodikai részben szívesen publikált Semmelweis is. Ami a szemészeti mellékletet illeti: az ún. kisebb orvosi szakmák közül Magyarországon az oftalmológiának volt legelőször önálló tanszéke, s annak számos kiválósága volt, köztük említendő a Grósz dinasztia. A közegészségügy nemzetközi hírü tudósa és szervezője volt Fodor József, ő is és kollégái is szívesen publikáltak a Hetilapban. A szerkesztők igyekeztek mindent megtenni annak érdekében, hogy információközvetítésben valóban élen járjanak, s a fóbb külföldi tudományos felismerések - legalább hírek formájában - bekerüljenek a lapba.

Az Orvosi Hetilap szerkesztési elveivel nem mindenki értett egyet, köztük a társszerkesztő Poór Imre sem, aki kivált onnan, s 1860-ban megindította a Gyógyászatot. Annak ellenére, hogy az új szaklap megalapítása személyes ellentétek miatt történt, 
a magyar orvostudománynak javára vált a két lap versenye. Poór a Gyógyászat mellé kiadta $A$ szükségesb orvosi müszavak deák-magyar-német zsebszótára című szómagyarázó könyvecskét is. Ahogy az előszóban írja: „A zsebszótár-szerkesztésben érdemes nyelvbúvárok, Bugát és Pólya tudorok és magyar akadémia r. tagok orvostermészettudományi műszógyüjteménye szolgált alapul”. Ennyiben Poór is igazodott az Akadémia elvárásaihoz, s a használható szaknyelv kialakításához.

A Gyógyászat megindulásával két, egymással szembenálló közösség jött létre a honi orvoslás színterein, vitáik éveken át uralták a gyógytudományt és elsősorban az egyetemi életet.

Ami az orvosi szakkönyveket illeti, Semmelweis alapmüvét, azóta világhírűvé lett Die Aetiologie, der Begriff und die Prophylaxis des Kindbettfiebers című munkáját a Pesten, Bécsben és Lipcsében is működő könyvkiadó tulajdonosa, a szerző személyes barátja, Hartleben Konrád Adolf adta ki 1860-ban. Munkája nem lett egyetemi tankönyv. Az orvosi szakkönyvek és tankönyvek iránti igény viszont fokozódott, köszönhetően a Pesten működő (idén 250 éves) Orvosi Karnak is, s így 1863-ban Markusovszky Lajos létrehozta a Magyar Orvosi Könyvkiadó Társulatot. ${ }^{36}$ Sorozatukban (Magyar Orvosi Könyvkiadó Társulat Könyvtára) magyar szerzők művei mellett számos kötetet vettek át és fordíttattak le magyarra. 1895 végéig a társulat kiadványai közül az idegen nyelvekből fordított munkák száma 63, a magyar szerzőktől írt eredeti munkáké pedig 31 volt. Ez afféle sikertörténetnek hangzik, de nem minden kiadványuk volt valóban naprakész. 1870-ben például kiadták - elsősorban az egyetemi hallgatók számára - Naegele Szülészeti tankönyvét, amely sorozatuk 14. kötete volt, de ez a munka meg sem említette Semmelweis felfedezését és a gyermekágyi láz kórtana tekintetében teljesen elavult nézeteket közölt. Szomorú, hogy a könyv fordítója sem hívta fel a kiadó figyelmét a kötet gyenge, korrigálandó pontjaira. Mindez tíz évvel Semmelweis könyve megjelenése után történt! Úgyhogy információközvetítésben a kiadó és az orvosi társadalom nem mindig állt a helyzet magaslatán.

\section{A Magyarhoni Földtani Társulat és a Magyar Mérnök- és Építész-Egylet közösségépitö szerepe}

Az 1867 előtti időszakból még két reáltudományi egyesületről tudunk beszámolni, az egyik a müködését 1850-ben megkezdő Magyarhoni Földtani Társulat, a másik az 1867-től müködő Magyar Mérnök- és Építész-Egylet.

A földtan hazai kutatói már a XVIII. században is szép számban munkálkodtak, s komoly háttérintézményük volt az 1770-ben akadémiai rangra emelt felsőoktatási intézmény, a Selmeci Bányászati Akadémia. Ehhez kapcsolódott az 1868 óta megjelenő Bányászati és Kohászati Lapok. 


\section{Gazda István}

A Magyar Orvosok és Természetvizsgálók 1847-es Vándorgyülésén határozták el, hogy önálló földtani társulatot is életre hívnak, ez meg is alakult 1848-ban, de müködési engedélyét csak 1850-ben kapta meg. A társulat első alapszabályát Zipser Keresztély András vezetésével dolgozták ki. A társulat első vezetői lettek: Kubinyi Ágoston elnök (a Magyar Nemzeti Múzeum igazgatója), Kubinyi Ferenc alelnök, Szabó József másodtitkár, az elnökségi tagok egyike pedig a korábban már említett Petényi Salamon János volt. Többségük akadémiai tag is volt. Nyomtatásban megjelent munkálataiknak első füzete 1856-ban került ki a sajtó alól, Kováts Gyula szerkesztésében. Ennek folytatása a Földtani Közlöny, amely 1871 óta havonta megjelenik, napjainkban is.

A mérnökök szervezete Magyar Mérnök Egyesület néven, 627 taggal alakult meg 1867 májusában, később az építészek is csatlakoztak hozzájuk. Periodikájuk, a Magyar Mérnök-Egylet Közlönye szintén 1867-ben indult, amely 1872-től bővített föcímmel, Magyar Mérnök- és Építész-Egylet Közlönye néven jelent meg, egészen 1944ig. Legfőbb háttérintézményük a Műegyetem, s annak jogelőd intézményei voltak. Maga a Műegyetem az 1782-es budai mérnökképzőt tekinti alapító elődjének. Itt indult meg a polgári mérnökképzés hazánkban.

\section{Összegzés}

A fentiekben arra kerestünk választ, melyek voltak a reáltudományok művelői körében az információközvetítés és közösségépítés legföbb színterei a történelmi Magyarországon az 1825 és 1867 közötti időszakban. Láttuk, hogy az első hazai tartós életű tudóstársaságok a reformkortól kezdve kaphattak működési engedélyt, élükön a Magyar Tudós Társasággal, de a hatalom fenntartotta magának a jogot a megjelenő cikkek és könyvek cenzúrázására. A társaságok igyekeztek nagyobb háborúságok nélkül együttműködni a hatalommal az információközvetítés szabadságát akadályozó rendelkezések betartásában, ez a reáliák területén általában sikerült is, a társadalomtudományokban nem mindig.

Az OSZK Kézirattárában magunk is találtunk olyan reformkori akadémiai kéziratot, amelyben egyes bekezdéseket a cenzor kihúzott, majd a megjelent nyomtatványt ellenőrizve láttuk, hogy az akadémikus anyaga valóban a meghúzott formában látott napvilágot. Ugyanez vonatkozott mindenkire, így Széchenyi is kénytelen volt a Hitel, a Világ és a Stádium szövegét is beadni a cenzornak, az első kettő esetében a cenzori kívánalmaknak eleget is tett, a harmadik esetében azonban nem, ez a munkája cenzori húzások és módosítások nélkül jelent meg, de nem idehaza, hanem Lipcsében. Utóbbi igaz Wesselényi Balítéletekről című 1844-es munkájára is, amely a behozott könyveket ellenőrzendő revizorok munkáját félrevezetni volt hívatva azáltal, hogy hamis impresszummal (Bukarest) került ki a lipcsei sajtó alól. Bukarestnek ekkor nagyobb könyvnyomdája még nem volt, ezért a mü ott nem is készülhetett. ${ }^{37}$ 
A tudós társadalom közösségépítésének színterei a társaságok, egyletek voltak, valamint az általuk szervezett nagygyülések, vándorgyülések, felolvasó estek, továbbá a társaságokhoz kötődő periodikákhoz kapcsolódó tanácskozások.

A nehézkes közlekedés pedig azt igényelte, hogy minden vármegye igyekezzen legalább egy reáltudományi egyletet fenntartani, s saját információközvetítő szerepüket, fontosságukat periodikákkal, éves konferenciákkal is hírül adni. Az egyes szakmák pedig igyekeztek külön-külön közösséget alkotni: láttuk, hogy az orvosok és gyógyszerészek szinte minden megyében önálló kört hoztak létre, a földtan tudósai éppúgy maguk igyekeztek müködni, akárcsak a mérnökök. Az egyletek általában elküldték egymás könyvtárainak periodikáikat, kiadványaikat, az Akadémia ezt tette a külföldi akadémiák esetében is, tehát lényegében tudtak egymás működéséről.

A társaságok közül többen is hirdettek pályakérdéseket (néha maguk az éves vándorgyülések is), ezek anyagi alapját többnyire családi emlékező adományok alkották: a pályadíj megnevezésével emlékeztettek arra a személyre, akinek a tiszteletére hozták létre a többnyire komoly összegü díjat. Sok ilyen díj volt, s a felhívásokra sok dolgozat született, nívósak és gyengécskék egyaránt.

A XVIII. században elindult, de végül is a XIX. századra alakult ki a tudósokat támogató mecenatúra intézménye. Ne feledjük, hogy maga az Akadémia is adományokra és pályadíjakra épült, s ezek képezték többnyire más körökben is a tudományos könyvkiadás alapját. Példaként említjük, hogy a neves bibliográfus, Szinnyei József és fia egy ilyen pályakérdés keretében adta közre az ország több évszázados matematikai és természettudományi könyvészetét összegző, száz arannyal jutalmazott bibliográfiáját, a Természettudományi Társulat jóvoltából.

A magyar szerzők kiemelkedő értékű alkotásai, valamint a nívós külhoni munkák magyar fordításai a XIX. századi információközvetítés legfontosabb eredményeinek tekinthetők.

\section{Irodalom és jegyzetek}

1. Ezek teljes jegyzékét lásd korábbi kötetünkben: GAZDA István: A Magyar Tudós Társaság által kiadott könyvek és folyóiratok 1831-1848. Budapest, MATI, 2018. 203 p. (Magyar Tudománytörténeti Szemle Könyvtára; 129.)

2. A Tudománytár 1834 és 1844 között jelent meg, 1850 és 1860 között valamennyi tudományágat az Uj Magyar Muzeum képviselt, 1861-ben indult a Mathematikai és Természettudományi Közlemények, majd 1867-ben az Értekezések a Természettudományok Köréből és az Értekezések a Mathematikai Tudományok Köréből.

3. Mathematikai műszótár. Közre bocsájtja a’ magyar tudós társaság. Budán, Egy. ny., 1834. VIII, $110 \mathrm{p}$.

4. Bolyai Farkas szóalkotásait lásd korábbi kötetünkben: Egy halhatatlan erdélyi tudós, Bolyai Farkas. Összeállította: GAZDA István. Budapest, Akadémiai Kiadó, 2002. 766 p. (Magyar Tudománytörténeti Szemle Könyvtára; 25.) 


\section{Gazda István}

5. Itt a matematika mellett már figyelembe vették Bugát Pál orvosi és Schuster János tanár úr vegytani nyelvújító javallatait is, amelyek néha igencsak furcsa szófacsarások voltak. Aztán néhány évtized alatt letisztult a nyelv, $s$ kialakultak a lényegében napjainkban is használatos müszavak. A lényeg az, hogy ez sok közösséget megmozgatott, nagy vitákat kavart, s mindenki igyekezett friss ötleteit gyorsan, sokak számára közreadni, hogy elérje, hogy az ő ötlete győzedelmeskedjen. Ezen a téren az információáramlás igencsak felgyorsult.

6. Bugát szellemes és kevésbé használható ötleteit egyaránt szótározta. Lásd: BUGÁT Pál: Természettudományi szóhalmaz. Buda, Egy. ny., 1843. 269 p.

7. id. SZILY Kálmán: A magyar nyelvújítás szótára. I-II. köt. Budapest, Hornyánszky, 1902, 1908. (Nemrégiben reprint kiadásban is megjelent, új utószóval.) Szily a téma további történeti kutatására akadémiai pályázatot is kiírt, amelynek nyertese Batta István lett. Utóbbi kéziratos hagyatéka, nyertes pályamunkája sokáig lappangott, s csak az elmúlt években kerültek napvilágra nyelvújítás-történeti gyüjtései. Lásd: BATTA István: A magyar fizikai szaknyelv fejlődése. A szerző kéziratos hagyatékából összeállította és sajtó alá rendezte: GAZDA István. Piliscsaba, MATI, 1999. 115 p. (Magyar Tudománytörténeti Szemle Könyvtára 10.); A magyar kémiai szaknyelv történetéből. A vegyészeti kifejezések történeti szótárával. A művet összeállította és bevezette: PACZOLAY Gyula. A könyvészeti fejezetet összeállította és a müvet sajtó alá rendezte: GAZDA István. A bibliográfia összeállításában közreműködött: PERJÁMOSI Sándor. A történeti szótár Batta István (1882-1926) 1921-ben íródott kéziratának felhasználásával készült. Piliscsaba, MATI, 2006. [2007]. 292 p. (Magyar Tudománytörténeti Szemle Könyvtára; 50.)

8. Az akadémiai évkönyvek csillagászati részeit minden évben Nagy Károly állította össze pl.: Astronomiai napló és kalendáriom 1840. Szerkeszté NAGY Károly. A’ m. tudós társaság’ költségén. Pesten, Ny.: Sollinger J. P. (Bécs), [1839]. 132, [2] p.

9. A’ természetes számok' logarithmai 1től 108000ig. Szerkezteté BABBAGE Károly. Stereotyp-harmadik kiadás. Készült NAGY Károly felügyelése alatt. A’ magyar tudós társaság' költségével. London, W. Clowes, 1834. [2], VII, XIV, 202 p.

10. A Társaság által 1867-ig kiadott matematikai művek többsége nem képviselt különösebb értéket, ahogyan az a társasági munkát bemutató összegzésből és kritikából is kitünik: VEKERDI László: A Tudománynak háza vagyon. Reáliák a régi Akadémia terveiben és müködésében. Sajtó alá rendezte GAZDA István. Piliscsaba - Budapest, MATI - TKME, 1996. 227 p. (Magyar Tudománytörténeti Szemle Könyvtára 1.). Gondolunk itt Győry Sándor, Vállas Antal, Brassai Sámuel, Nagy Károly és a kortárs matematikus akadémikusok dolgozataira. Publikációikról lásd bővebben: VÁLLAS Antal: Magyar legujabb mathematica literatura. = Tudománytár, Vol. 2. (1836). 143-172. p.

11. A helyzet csak 1867-ben kezd javulni, ekkor kerül ki a sajtó alól Petzval Ottó és Hunyady Jenő egy-egy akadémiai matematikai munkája.

12. GAZDA István: A tudománytörténész id. Szily Kálmán. = Fizikai Szemle, 62. évf. 7-8. sz. 2012. 221-226. p. és ua. Forrás: http://real.mtak.hu/19217/ [2019. augusztus 7.] - Szily kezdetben fizikával foglalkozott, 1867-ben a mechanikai hőelmélet témakörében jelent meg akadémiai dolgozata.

13. Lásd bővebben: Euklides Elemei. XV. könyv. Fordította: BRASSAI Sámuel. Pest, Akadémia,1865. XIV, 635 p. 
INFORMÁCIÓKÖZVETÍTÉS ÉS KÖZÖSSÉGÉPÍTÉS A REÁLTUDOMÁNYOK MÜVELŐI...

14. Lásd az Akadémiai Könyvtár Bolyai János honlapját. Forrás: http://bolyai.mtak.hu/ [2019. június 30.]

15. Az állat-ország fölosztva alkotása szerint alapul szolgálandó az állatok természetleirásához $s$ bevezetésűl az összehasonlitó bonctanhoz Cuvier báró által. Természet után rajzolt ábrákkal. A második átnézett és öregbített kiadás szerint fordította VAJDA Péter. I. kötet. A m. academ. költségein. Budán, Egy. ny., 1841. LX, 644 p.

16. A madártan kiváló kutatójának, Petényinek a műveiből az egyetlen modern válogatás közremüködésünkkel jelent meg: Petényi Salamon János (1799-1855) emlékezete. Összeállította és bevezette: MÉSZÁROS Ferenc. Sajtó alá rendezte: GAZDA István. Budapest - Piliscsaba, MATI - MTM, 2000. 179 p. (Magyar Tudománytörténeti Szemle Könyvtára; 22.)

17. Than életmüvének legjobb feldolgozása: BECK Mihály: Than Károly élete és munkássága. Sajtó alá rendezte és a bibliográfiai függeléket szerkesztette: GAZDA István. A bibliográfia összeállításában közreműködött: Perjámosi Sándor. Piliscsaba, MATI, 2008. 206 p. (Magyar Tudománytörténeti Szemle Könyvtára; 69.)

18. Fabini János' tanítmánya a’ szembetegségekről. A’ második javított kiadás után fordítá dr. VAJNÓCZ János. A m. tudós társaság’ költségein. Budán, Egy. ny., 1837. VI, 332, [2] p.

19. A magyarországi pokolvar, annak természete, okai, óvó és gyógymódjai. Irta TOPPERCZER Tamás. Első rangu pályamunka. + A’ magyarországi pokolvar, annak természete, okai, óvó és gyógymódjai. Irta CSORBA József. Másod rangu pályamunka. Budán, Egy. ny., 1837. VIII, 150 p. (Természettudományi pályamunkák; 1.)

20. Sebészség, mellyet előadási kézikönyvül kiadott dr. Chelius M. J. heidelbergi professor. A' negyedik öregbített és javított eredeti kiadat után a’ pesti m. kir. egyetembeli orv. kar' oskolai használatára fordítá BUGÁT Pál. I-IV. köt. Buda, Egy. ny., 1836-1839.

21. Lásd bővebben: Semmelweis Ignác emlékezete. Összeáll.: GAZDA István - KAPRONCZAY Károly - SZÁLLÁSI Árpád. 1-2. köt. Piliscsaba - Budapest, MATI - SOMKL - Semmelweis Egyetem, 2001. 556, 11 p. (Magyar Tudománytörténeti Szemle Könyvtára; 28.)

22. Megindult Heckenasték kiadásában is egy kereskedelmi célú könyvészet, amelyből három évfolyamnyi látott napvilágot: 1840-ről. = Bibliographiai Értesítő, 1840. 80, VIII p.; 1841-ről. = Bibliographiai Értesítő, 1841. 88, XX p.; 1842-ről. = Bibliographiai Értesítő, 1842. 32 p.

23. A reformkori kiadványokról jó áttekintést ad a Széchenyi kezdeményezésére létrejött Casino könyvtára: PÁKH Albert (összeáll.): Kalauz a Nemzeti Casino Könyvtárához. Pest, Trattner-Károlyi,1852. VI, 314 p. A Bach-korszakban megjelent kiadványokról pedig a jól ismert könyvjegyzék tájékoztat, amely a Honi irodalmi hirdető folytatásának tekinthető: MAGYAR Mihál: Az 1849-1857. évi magyar könyvészet. Tudományos szaksorozattal kiadja Demjén József. Pest, 1862. 224, 80 p.

24. Bővebben: KAPRONCZAY Károly (összeáll.): A Semmelweis Orvostörténeti Könyvtár története. Sajtó alá rend.: GAZDA István. Budapest, MATI - Johan Béla Alapítvány, 2017. 147 p. (Magyar Tudománytörténeti Szemle Könyvtára; 120.)

25. Számos előadást tartott Jedlik Ányos is a vándorgyüléseken, lásd ezek szövegét: Forrás: http://real.mtak.hu/30044/1/jedlik_eloadasai_teljes.pdf [2019. június 30.]

26. ZIPSER, A. C.: Die Versammlungen ungarischer Aerzte und Naturforscher ... Neusohl, Druck. Machold, 1846. XVIII, 238 p., 2 t.

27. Hippokrates aphorizmái. Fordítá 's a' magyar orvosok ’s természetvizsgálók negyedik nagy gyưlésének ajánlá WACHTEL Dávid. Temesváratt, Beichel József betüivel, 1843. 50 p. 


\section{Gazda István}

28. Buziás. Magyar orvosok és természetvizsgálók negyedik nagy gyülésének emlékeűl. Írá Dr. DEUTSCH Ferencz József. Temesváratt, Beichel József betüivel. 1843. 42, [1] p.

29. HAAS Mihály (szerk.): Baranya. Emlékirat. Pécsett, Nyomatott a’ lyceum’ könyvnyomóintézetében, $1845.350 \mathrm{p}$.

30. BITTNER Imre: A Bánság poslázairól. Pesten, A szerző saját költs. Nyomatott Beimel Józsefnél, 1847. VIII, $111 \mathrm{p}$.

31. MOCSI Mihály: Felelet a Természettudományi Egyesülettől feltett következő kérdésre: Adassék elő a természettudományok nagy jelentősége ... Pesten, Nyomatott Beimel Józsefnél, 1846. 58 p.

32. PATRUBÁNY Gergely: Virchow Sejtkórtanának ismertetése. Pest, Emich ny., 1863. VI, $105 \mathrm{p}$.

33. BALASSA János: Új mütétmodorok az orrképlés körül. Két kóresettel és tizenegy kőre rajzolt táblával közli a Magyar Orvosok és Természetvizsgálók IX. nagygyűlése alkalmára. Pest, Emich Gusztáv, 1863. 22 p., XI. t.

34. Lásd bővebben: A százhetvenöt éves Tudományos Ismeretterjesztő Társulat (1841-2016). Az elnökök munkásságának tükrében. Összeállította: GAZDA István. Az ajánlást írta: Piróth Eszter. A szerkesztés a Magyar Tudománytörténeti és Egészségtudományi Intézetben készült. Budapest, TIT, 2016. 191 p.

35. A 150. évfordulóra monográfia is megjelent a lapról: FEHÉR János - GAZDA István SZÁLLÁSI Árpád (szerk.): Emlékkönyv az Orvosi Hetilap alapításának 150. évfordulójára. Budapest, Markusovszky Lajos Alapítvány - MATI - Akadémiai Kiadó, 2007. 160 p. (Magyar Tudománytörténeti Szemle Könyvtára 66.); ehhez kapcsolódik: Semmelweis Ignác magyar nyelvü szaktanulmányai az Orvosi Hetilap 1858-1865-ös évfolyamaiban. Győry Tibor 1909-ben írt kísérőtanulmányával. Összeállította és sajtó alá rendezte: GAZDA István. Budapest, MOT-MATI, 2013. 163 p. 1 t. (Magyar Tudománytörténeti Szemle Könyvtára; 99.) Lásd az előzményekről: DÖRNYEI Sándor: Elvetélt orvosi folyóirat-tervek az Orvosi Hetilap megindulásáig. = Orvosi Hetilap, 145. sz. 2013. 958-960.

36. Az addig megjelent művekről jó tájékoztatást nyújt a kari könyvtár jegyzéke: $\mathrm{A} \mathrm{m} . \mathrm{k}$. Tudomány-Egyetem orvostanárkari könyvtár jegyzéke. [Összeáll.: SEMMELWEIS Ignác]. 1-2. köt. Pest, Emich, 1864. 156, 176 p.

37. Lásd bővebben: GAZDA István: Könyvkereskedők a régi Váci utcában a pesti könyvnyomtatás első száz évében. Budapest, Akadémiai Kiadó, 1988. 116 p.; GAZDA István: Száz év a pesti könyvkereskedelem és szakkönyvkiadás történetéből 1748-1848. Különös tekintettel a reáltudományi kiadványokra. Budapest, MATI, 2017. 234 p. (Magyar Tudománytörténeti Szemle Könyvtára; 117.)

Gazda István tudománytörténész, a történelemtudomány kandidátusa, a Magyar Tudománytörténeti és Egészségtudományi Intézet igazgatója. Kutatási területe a magyarországi csillagászat, fizika és matematika története, orvostörténet. 